\title{
UMBATRA
}

Indonesian Journal of Anthropology

Volume 6 (1) Juli 2021 || eISSN 2528-1569 | pISSN 2528-2115 || http://jurnal.unpad.ac.id/umbara

DOI : 10.24198/umbara.v6i1.30667

\section{Pergeseran Solidaritas Komunitas Adat Cijere dalam Mempertahankan Eksistensi Rumah Adat}

\author{
Theresia Martina Marwanti \\ Program Studi Pekerjaan Sosial, Politeknik Kesejahteraan Sosial Bandung \\ martina.wanti@gmail.com
}

\begin{abstract}
This research describes shifting in the social solidarity of Cijere traditional community in maintaining their traditional house. This research applied descriptive qualitative method. Data of this study were collected through in-depth interviews, observation and documentation. Six informants of this research were selected based on purposive sampling technique. The result of this research shows that the type of solidarity in Cijere traditional community has shifted from mechanical solidarity to organic solidarity. This shifting strongly influenced by structural, cultural, and interactional dimensions; and it affects the existence of the traditional house. The meaning of the traditional house for Cijere traditional community has also changed; as some people no longer consider the importance of traditional house for their daily lives.
\end{abstract}

Keywords: solidarity, Cijere traditional community, traditional house

\begin{abstract}
Abstrak
Artikel ini membahas pergeseran solidaritas sosial dalam mempertahankan eksistensi rumah adat di komunitas adat Cijere. Penelitian ini menggunakan metode deskriptif kualitatif. Teknik pengumpulan data dilakukan melalui wawancara mendalam, observasi, dan studi dokumentasi. Enam orang informan dalam penelitian ini dipilih berdasarkan teknik purposive sampling. Hasil penelitian menunjukkan bahwa jenis solidaritas pada komunitas adat Cijere telah mengalami pergeseran dari solidaritas mekanik ke solidaritas organik. Pergeseran solidaritas ini sangat dipengaruhi oleh dimensi struktural, kultural, dan interaksional. Pergeseran solidaritas yang terjadi memengaruhi makna rumah adat bagi komunitas adat Cijere. Saat ini, tidak semua anggota komunitas adat Cijere menganggap rumah adat sangat penting bagi kehidupan mereka.
\end{abstract}

Kata kunci: solidaritas, komunitas adat Cijere, rumah adat

\section{Pendahuluan}

Rumah adat bantuan dari Gubernur Jawa Barat

kekhasan komunitas adat Cijere. Rumah adat tahun 2008 menjadi salah satu keunikan atau di komunitas Cijere berbeda dibandingkan 
dengan rumah adat pada umumnya yang merupakan tempat tinggal pribadi. Rumah adat di komunitas Cijere merupakan milik bersama, seperti aula, berbentuk panggung, tempat mereka melakukan pertemuan dan melakukan kegiatan seperti mubur suro ${ }^{l}$ dan ngalak$s \mathrm{a}^{2}$ yang sangat sakral, dan kegiatan kolektif lainnya. Namun, meski bukanlah warisan leluhur, istilah "rumah adat" tetap digunakan warga untuk menyebut bangunan tersebut.

Rumah adat komunitas Cijere merupakan tempat yang paling strategis untuk mengadakan setiap kegiatan yang berkaitan dengan upacara adat, penyambutan tamu, rapat desa, dan setiap pertemuan yang mengundang banyak warga. Kegiatan-kegiatan yang dilaksanakan di rumah adat ini memerlukan sarana pendukung antara lain dapur umum, sarana penerangan, dan sarana air bersih, agar kegiatan dapat berjalan dengan baik. Oleh karena itu, rumah adat memerlukan pemeliharaan secara berkala untuk meningkatkan kebersihan, keindahan, dan kenyamanan rumah adat. Namun, sayangnya hal ini tidak terlaksana. Rumah adat di komunitas Cijere justru terlihat semakin tidak terawat, kotor, kumuh, dan sangat memprihatinkan. Sarana dan prasarana di sekitar rumah adat, seperti listrik, dapur umum, dan MCK sudah tidak dapat lagi digunakan. Hal ini disebabkan oleh kurangnya sense of belonging di antara anggota komunitas adat Cijere terhadap eksistensi rumah adat tersebut. Mereka saling melempar tanggung jawab ketika ditanyakan siapa yang seharusnya bertanggung jawab untuk mempertahankan eksistensi rumah adat. Solidaritas komunitas adat Cijere dalam mempertahankan eksistensi rumah adat cenderung menurun. Solidaritas yang selama ini terpupuk dengan baik, semakin luntur.

Menurut komunitas adat Cijere, dahulu setiap warga secara sukarela mau memelihara, membersihkan, dan merawat rumah adat. Namun, sekarang sangat sulit untuk mengajak warga terlibat dalam kegiatan tersebut. Sifat individualis mulai nampak lebih menonjol di kalangan warga. Saat ini keterlibatan warga dalam aktivitas kehidupan kolektif cenderung berorientasi pada materi (uang).

Secara geografis, komunitas Adat Cijere terletak di Desa Nagarawangi Kecamatan Rancakalong Kabupaten Sumedang. Berdasarkan rekomendasi Bupati Subang, Cijere merupakan salah satu lokasi program pemberdayaan Komunitas Adat Terpencil tahun 2008. Oleh karena itu, Gubernur Jawa Barat membangun rumah adat di komunitas adat Cijere untuk mewadahi, menyalurkan, dan membina warga komunitas adat dalam kegiatan kemasyarakatan sehingga mampu menumbuhkan rasa gotong royong dan kebersamaan. Eksistensi rumah adat juga dapat mewadahi dan mempererat tali silaturahmi antar warga komunitas adat Cijere untuk melakukan kegiatan yang positif dan produktif.

Manusia pada hakikatnya adalah mahluk sosial yang memerlukan orang lain di sekitarnya. Namun, kemajuan ilmu pengetahuan dan teknologi sangat memengaruhi sifat individualis dan berdampak pada pembagian kerja dalam masyarakat. Durkheim dalam Johnson (1986) berpendapat bahwa masyarakat primitif memiliki kesadaran kolektif yang lebih kuat yaitu pemahaman norma dan kepercayaan bersama. Tiadanya pembagian kerja yang jelas menyebabkan menyusutnya kesadaran kolektif. Selanjutnya, Durkheim menekankan arti pentingnya pembagian kerja karena fungsi pembagian kerja adalah untuk meningkatkan solidaritas. Solidaritas menumbuhkan kepercayaan dan ketergantungan di antara para anggotanya.

Penelitian terdahulu tentang solidaritas pernah dilakukan oleh Wiganingrum (2013) yang menyebutkan bahwa pada masyarakat Desa Setren yang sebagian besar bermatapencaharian sebagai petani, ternyata masih mempertahankan nilai-nilai solidaritas dalam

\footnotetext{
${ }^{1}$ Mubur surro adalah tradisi masyarakat kampung Cijere dalam mengolah makanan bubur rasa manis yang terbuat dari seribu macam jenis tanaman yang ada di sekitar kampung Cijere.

${ }^{2}$ Ngalaksa adalah tradisi mengolah makanan yang terbuat dari beras yang ditumbuk dan direndam selama beberapa hari hingga rasanya manis berbau asam. Kegiatan ngalaksa biasanya dilaksanakan setiap empat tahun sekali.
} 
membersihkan saluran air dan membersihkan jalan. Penyebab bertahannya nilai-nilai solidaritas mekanik karena adanya homogenitas pekerjaan, yang tidak menuntut mereka untuk melakukan pekerjaan berdasarkan pembagian kerja yang tegas/kaku.

Perubahan nilai-nilai solidaritas bisa terjadi karena adanya faktor pendorong tertentu. Sembiring (2014) menyebutkan faktor sosial, faktor ekonomi dan faktor lapangan pekerjaan dapat menjadi pertimbangan masyarakat untuk menentukan sikap solidaritas terhadap lingkungannya. Berdasarkan hasil penelitian Saidang dan Suparman (2019), solidaritas merupakan bagian dari masyarakat yang tidak terpisahkan. Hal ini karena walaupun setiap anggota masyarakat memiliki peran dan fungsi yang berbeda-beda, mereka masih tetap berada dalam satu kesatuan.

Penelitian tentang solidaritas sosial ataupun perilaku kolektif telah dilakukan oleh Khaidir (2006) dalam Funay (2020). Ia menyatakan bahwa kesadaran kolektif penting untuk menjadi landasan yang mendorong lahirnya komunitas yang plural tanpa memandang kelas, strata ekonomi, dan budaya. Aspek terpenting dari sebuah komunitas yang plural adalah setiap anggotanya mampu berpartisipasi aktif mendorong terciptanya gerakan kreatif dan progresif ketika bersinggungan dengan kepentingan bersama.

Penelitian lain yang dilakukan Nuraiman (2019) tentang solidaritas masyarakat di Nagari Solok Ambah Kabupaten Sijunjung menunjukkan bahwa masyarakat di nagari ini memiliki tingkat solidaritas yang sangat tinggi. Sikap solidaritas itu tercermin dalam kebersamaan dan gotong royong yang mereka lakukan dalam berbagai kegiatan. Masyarakat di sana memiliki kesadaran kolektif yang tinggi, tidak individualistis, menyelesaikan segala persoalan dengan cara kekeluargaan, dan memperhatikan norma-norma yang berlaku dan bersifat pedesaan. Bangunan-bangunan yang dibutuhkan untuk kepentingan umum, seperti masjid-masjid atau musala-musala, sekolah, balai adat, bahkan sampai ke rumah kemenakan yang baru menikah dan belum mampu membangun rumah dilaksanakan secara gotong royong. Seiring berkembangnya zaman, solidaritas yang dimiliki oleh masyarakat di Nagari Solok Ambah tersebut mulai memudar. Hal ini disebabkan oleh munculnya individualisme di kalangan masyarakat, kesadaran kolektif yang mulai melemah, hukum yang biasanya represif menjadi restitutif, tingginya ketergantungan, bersifat kekota-kotaan dan sebagainya. Masyarakat sekarang enggan mengikuti kegiatan gotong royong dan tidak memperlihatkan sikap solidaritas antar sesama. Kegiatan gotong royong cenderung hanya dilaksanakan oleh para orang tua saja, sementara para generasi muda tidak mengindahkan lagi solidaritas dalam bentuk gotong royong.

Berdasarkan beberapa hasil penelitian terdahulu, peneliti semakin tertarik untuk mengetahui sejauh mana pergeseran solidaritas yang terjadi di komunitas adat Cijere yang walaupun masyarakatnya masih dapat dikategorikan homogen, tetapi telah mengalami pergeseran solidaritas.

\section{Kajian Pustaka}

\section{Solidaritas}

Konsep solidaritas sosial merupakan konsep sentral Emile Durkheim dalam mengembangkan teori Sosiologi. Durkheim dalam Johnson (1986) menyatakan bahwa solidaritas sosial merupakan suatu keadaan hubungan antara individu dan/atau kelompok yang didasarkan pada perasaan moral dan kepercayaan yang dianut bersama dan diperkuat oleh pengalaman emosional bersama.

Solidaritas sosial dipengaruhi adanya interaksi sosial yang berlangsung karena ikatan kultural, yang pada dasarnya disebabkan oleh munculnya sentimen komunitas (community sentiment). Menurut Redfield dalam Johnson (1986), sentimen komunitas mempunyai unsur-unsur sebagai berikut: a) seperasaan, yaitu karena seseorang berusaha mengidentifikasi dirinya dengan sebanyak mungkin orang dalam kelompok tersebut sehingga dapat menyebutkan dirinya sebagai kelompok kami (warga); 
b) sepenanggungan, yaitu setiap individu sadar akan peranannya dalam kelompok yang dijalankan; c) saling membutuhkan, yaitu individu yang merasakan dirinya tergantung baik secara fisik maupun psikologis pada komunitasnya.

Durkheim membagi dua tipe solidaritas, yaitu solidaritas mekanik dan solidaritas organik (Sunarto, 2004). Secara terperinci, Johnson (1986) menegaskan indikator sifat kelompok sosial/masyarakat yang didasarkan pada solidaritas mekanik, yakni pembagian kerja yang rendah, kesadaran kolektif yang kuat, hukum represif dominan, individualitas rendah, konsensus terhadap pola normatif penting, adanya keterlibatan komunitas dalam menghukum orang yang menyimpang, secara relatif sifat ketergantungan rendah, dan bersifat primitif atau pedesaan. Di sisi lain, Johnson (1986) menegaskan indikator sifat kelompok sosial/masyarakat yang didasarkan pada solidaritas organik, yakni pembagian kerja rendah, kesadaran kolektif lemah, hukum restitutif (memulihkan) dominan, individualistis yang tinggi, konsensus pada nilai abstrak dan umum penting, badan-badan kontrol sosial menghukum orang yang menyimpang, saling ketergantungan tinggi, dan bersifat industrial perkotaan.

\section{Faktor Penyebab Bergesernya Solidaritas Sosial}

Menurut Himes dan Moore dalam Soelaiman (1998), ada tiga jenis atau dimensi yang memengaruhi perubahan solidaritas yaitu dimensi struktural, kultural dan interaksional. Dimensi struktural merujuk pada perubahan dalam bentuk struktural masyarakat, menyangkut perubahan dalam peranan, memunculkan peranan baru, perubahan dalam struktur kelas sosial, dan dalam lembaga sosial.

Dimensi perubahan struktur meliputi: a) bertambahnya atau berkurangnya kadar peranan; b) menyangkut aspek perilaku dan kekuasaan; c) adanya peningkatan atau penurunan sejumlah peranan atau pengkategorian peranan; d) terjadinya pergeseran wadah atau pengkategorian peranan; e) terjadinya modifikasi saluran komunikasi di antara peranan, dan f) terjadinya perubahan dari sejumlah tipe dan daya guna fungsi sebagai akibat dari struktur (Soelaiman, 1998).

Perubahan dalam dimensi kultural meliputi hal-hal sebagai berikut: a) inovasi kebudayaan, seperti penemuan, peniruan, atau peminjaman alat-alat; b) difusi, seperti penyimpangan kebudayaan dan difusi secara benar; c) integritas, seperti penolakan terhadap bentuk-bentuk baru, cara hidup lama, dan penggantian bentuk-bentuk lama dengan bentuk-bentuk baru (Nasution, 2009).

\section{Komunitas Adat}

Komunitas adat sering kali dipadankan dengan masyarakat adat. Definisi masyarakat adat menurut hasil Kongres I Masyarakat Adat Nusantara tahun 1999 menyatakan bahwa:

"Masyarakat adat adalah komunitas-komunitas yang hidup berdasarkan asal usul secara turun menurun di atas suatu wilayah adat, yang memiliki kedaulatan atas tanah dan alam, serta kehidupan sosial budaya yang diatur oleh hukum adat dan lembaga adat yang mengelola keberlangsungan kehidupan masyarakat. Secara keturunan dikatakan bahwa masyarakat adat terikat oleh hukum adat, keturunan, dan tempat tinggalnya." (Haba, 2010).

Konvensi 107 tahun 1957 dan 169 tahun 1989 dari International Labor Organization telah menggariskan isu-isu krusial yang berkaitan dengan masyarakat adat atau "indigenous people" antara lain: 1) mengidentifikasikan dan melindungi masyarakat adat; 2) mengakui hak-hak sosial, budaya dan ekonomi masyarakat adat; 3) mengkonsultasikan dengan masyarakat adat tentang hukum yang mereka anut/akui; 4) menghormati adat masyarakat adat; dan 5) melindungi sumber daya alam masyarakat adat (Haba, 2010).

Selanjutnya, Haba (2010) menyebutkan ciri-ciri yang membedakan masyarakat adat dengan masyarakat lainnya, yaitu: mendiami 
tanah nenek moyangnya, baik seluruhnya atau sebagian; mempunyai garis keturunan yang sama yang berasal dari penduduk asli daerah tersebut; mempunyai budaya yang khas yang menyangkut agama, sistem suku, pakaian, tarian, cara hidup, peralatan hidup sehari-hari, termasuk untuk mencari nafkah; mempunyai bahasa tersendiri; dan biasanya hidup terpisah dari kelompok masyarakat lain dan bersikap hati-hati terhadap hal-hal baru yang berasal dari komunitasnya.

\section{Adat Istiadat}

Istilah adat istiadat sering kali diganti dengan adat kebiasaaan, tetapi pada dasarnya memiliki arti yang sama. Adat istiadat adalah bagian dari tradisi sehingga adat atau tradisi ini dapat dipahami sebagai pewarisan atau penerimaan atas norma-norma adat. Adat istiadat mempunyai akibat-akibat apabila dilanggar oleh masyarakat yang tinggal di lingkungan adat istiadat tersebut berlaku.

Adat istiadat bersifat tertulis dan terpelihara turun temurun, sehingga mengakar dalam masyarakat. Adat istiadat komunitas adat Cijere saat ini sudah mengalami banyak pergeseran. Aturan-aturan tertulis dan tidak tertulis sudah tidak seketat masa lalu.

\section{Rumah Adat}

Rumah adat yang ditemukan di komunitas adat Cijere bukanlah rumah tempat sesepuh adat dan keluarganya untuk tinggal. Oleh karena itu, rumah adat tersebut lebih tepat disebut sebagai bangunan adat, tempat kegiatan berbagai upacara adat dilakukan. Namun, hingga kini masyarakat setempat tetap menyebutnya dengan istilah rumah adat. Oleh karena itu, peneliti tetap menggunkan istilah "rumah adat" dalam artikel ini.

Fungsi rumah adat pada umumnya digunakan sebagai tempat untuk berlindung dari bahaya. Fungsi dan bentuk rumah pun berubah-rubah sesuai dengan kecenderungan dan kebutuhan pada masa yang sedang berlangsung. Kesederhanaan bentuk, imajinasi seni, pemaknaan, dan nilai ruang pada masa lalu merupakan suatu hal yang bermanfaat untuk kita pahami sebagai pijakan dalam memaknai setiap unsur dan ruang sebuah rumah pada saat ini.

Pada umumnya rumah adat tradisional Sunda terbagi menjadi tiga bagian yaitu: hareup (depan), tengah imah (bagian tengah), dan tukang (bagian belakang). Bagian depan disebut tepas atau emper, digunakan sebagai tempat menerima tamu laki-laki. Tepas di Baduy disebut juga sosoro dan ada yang diberi tambahan yang disebut sosompang (khusus di rumah Jaro). Sejajar dengan tepas, biasanya ada kamar yang disediakan untuk tamu. Bagian tengah terdiri dari pangkeng (bilik) yang kadang-kadang memakai batas dengan dinding bilik, tapi ada juga yang tidak. Pangkeng atau enggon adalah tempat untuk tidur. Di dalam rumah yang agak besar, bagian tengah ini biasanya memiliki ruangan untuk berkumpul anggota keluarga. Bagian belakang rumah terdiri dari dapur dan goah. Bagian ini biasanya hanya dapat diakses oleh perempuan. Laki-laki tidak boleh masuk ke dapur apalagi goah jika tidak ada kepentingan yang sangat mendesak karena dianggap pamali (tabu). Selain berfungsi sebagai tempat memasak, dapur juga sering dipakai untuk menerima tamu perempuan (Saputra dan Satwikasari, 2019).

Rumah adat masyarakat Sunda pada zaman dahulu umumnya memiliki tiang berbahan bambu. Hal ini merujuk pada peribahasa hejo tihang, yaitu sebutan untuk orang yang selalu berpindah rumah. Lantai rumah adat Sunda terbuat dari talupuh atau palupuh, yaitu batang-batang bambu yang dibelah dan dicacah, tapi tidak sampai terpisah, lalu diratakan dengan panggungnya (yang bersembilu) di bagian atas. Bekas cacahan memungkinkan udara leluasa masuk dari kolong rumah. Oleh karena itu, pertukaran udara dalam rumah berlangsung dengan baik melalui lantai palupuh dan celah-celah dinding bilik, walaupun pada umumnya rumah tradisional tidak mempunyai jendela atau lubang angin. Hal yang menarik dari rumah adat komunitas Cijere adalah sebagian besar materi penyusun rumah ini terbuat dari kayu yang berbeda dari rumah adat Sunda 
pada umumnya.

Rumah adat Sunda juga biasanya dilengkapi dengan tangga untuk naik ke bagian depan rumah yang disebut golodog atau babancik (pada rumah tembok). Rumah panggung dengan tatapakan batu ini, secara teknis dapat bertahan dari guncangan gempa bumi, sehingga cocok dengan alam priangan yang banyak gunung apinya yang masih aktif.

\section{Metode}

Penelitian ini menggunakan metode penelitian deskriptif-kualitatif. Metode penelitian kualitatif adalah prosedur penelitian yang menghasilkan data deskriptif berupa kata-kata tertulis atau lisan dari orang-orang atau perilaku yang dapat diamati.

Pendekatan kualitatif digunakan untuk menggambarkan dan memahami kondisi sosial yang dimiliki subjek secara keseluruhan. Penelitian ini mempunyai kaitan dengan subjek yang mempunyai kekhususan terutama berkaitan dengan solidaritas komunitas adat $\mathrm{Ci}$ jere dalam mempertahankan eksistensi rumah adat. Penelitian ini mencoba menggali lebih jauh tentang proses yang dilakukan komunitas adat dalam mempertahankan eksistensi rumah adat, sehingga perlu penajaman dalam penelaahannya. Melalui pendekatan kualitatif, peneliti terbuka menerima banyak data yang ada di luar jangkauan atau data yang berbeda dengan apa yang diidentifikasi di dalam penelitian yang dilakukan.

Penggunaan metode kualitatif memungkinkan peneliti untuk berada langsung dan membaur bersama-sama dengan masyarakat yang ditelitinya. Maksud dan tujuannya adalah agar penelitian ini dapat memberikan gambaran secara mendetail dan mendapatkan keabsahan data yang objektif dari sasaran penelitian ini, yakni komunitas adat Cijere.

Informan dalam penelitian ini terdiri atas 6 informan, yang dipilih secara purposive. Teknik pengumpulan data melalui wawancara mendalam, observasi dan studi dokumentasi.

\section{Hasil dan Pembahasan}

Komunitas adat Cijere tinggal di suatu dusun di wilayah Desa Nagarawangi. Dusun atau kampung Cijere terletak kurang lebih $1,5 \mathrm{~km}$ dari ibukota Kecamatan Rancakalong, dan 12 km dari ibukota Kabupaten Sumedang. Batas wilayah Dusun Cijere adalah: sebelah utara: Dusun Lebak Tulang dan Kampung Citungku, sebelah timur: Desa Pangadegan, sebelah selatan: Desa Pamekaran, dan sebelah barat: Desa Cibunar.

Masyarakat di Komunitas Adat Cijere, dibagi menjadi dua yaitu kelompok rurukan (masyarakat yang masih memiliki ikatan dengan leluhur) dan bukan rurukan (masyarakat desa pada umumnya). Rurukan dikenal juga dengan istilah katurunan mubur. Komunitas kerabat yang masuk ke dalam rurukan memiliki kewenangan khusus untuk mempertahankan dan melaksanakan tradisi leluhur berupa mubur sura dan ngalaksa.

Tradisi mubur sura dan ngalaksa di komunitas adat Cijere adalah salah satu alasan kampung Cijere disebut sebagai komunitas adat. Keberadaan komunitas adat ini juga diperkuat oleh rekomendasi Bupati Subang no. 141/0621/ Dinsos/PMD, sehingga kampung Cijere dijadikan lokasi program kegiatan Pemberdayaan Komunitas Adat terpencil (KAT) pada 2008.

\section{Makna Rumah Adat}

Rumah adat yang ada di Cijere hanya satu dan berbeda dengan rumah adat pada umumnya. Rumah ini disebut rumah adat karena selalu digunakan untuk acara-acara adat/budaya seperti adat bubur suro, pengajian Al-Qur'an, pertemuan tokoh-tokoh adat, dan berbagai acara hiburan lainnya. Namun, kegiatan adat ngalaksa harus dipusatkan di kecamatan Rancakalong.

Rumah adat dibangun pada awal tahun 1998 oleh Kementerian Sosial melalui program pemberdayaan KAT. Rumah adat menghadap ke selatan-utara dengan luas tanah 21 tumbak atau sekitar $294 \mathrm{~m}^{2}$, luas bangunan $8 \times 15 \mathrm{~m}^{2}$, berbentuk joglo, terbuat dari kayu dan bambu. Rumah adat di Cijere memiliki bentuk 
panggung, sehingga memiliki kolong. Jarak kolong diukur setinggi lutut atau sekitar 40 $\mathrm{cm}$. Kolong berfungsi sebagai bentuk penghormatan terhadap unsur kehidupan di dalam tanah karena adanya kolong menjadi ruang bagi bumi untuk tetap bernapas.

Namun, sayangnya saat ini kondisi fisik rumah adat komunitas Cijere sudah sangat memprihatikan.

"Kayu sudah reyot, bisa ambruk, reng-rengnya sudah rusak, bambu-bambu dimakan rayap. Dapur dan WC sudah tidak bisa digunakan lagi. Beda dengan dulu, bagus dan terawat." (Wawancara dengan Engkus, 17 September 2018)

Kondisi rumah adat komunitas Cijere yang sudah memprihatinkan menimbulkan kekhawatiran warga. Mereka takut apabila rumah adat akhirnya tidak dapat dipakai lagi untuk aktivitas kehidupan komunitas adat Cijere.

Warga komunitas adat Cijere berharap rumah adat tetap dipertahankan dan tidak boleh hilang sampai kapan pun. Mereka menganggap apabila rumah adat hilang, maka adat istiadat mereka juga akan hilang, dan dengan sendirinya komunitas adat Cijere pun akan hilang. Hal ini merupakan suatu bentuk keprihatinan yang harus disikapi dengan bijaksana.

\section{Jenis/Tipe Solidaritas Komunitas Adat Ci- jere}

Pembangunan rumah adat di komunitas Cijere pada tahun 2008 menjadi kebanggaan tersendiri bagi warga. Hampir semua elemen masyarakat merasa harus turut memelihara dan bertanggung jawab atas eksistensi rumah adat. Rumah adat terlihat bersih, asri, dilengkapi dengan dapur umum yang digunakan sebagai tempat memasak hidangan untuk menjamu tamu, dan toilet bersih yang dapat digunakan oleh pengunjung. Warga bergotong-royong dalam melakukan kerja bakti membersihkan rumah adat, memasak hidangan, menyiapkan alat-alat sound system, dan menyiapkan kesenian Tarawangsa untuk menyambut tamu.
Pada umumnya, solidaritas sosial yang lebih dominan pada masyarakat pedesaan adalah solidaritas mekanik. Hal ini didukung oleh tingkat homogenitas mereka yang masih tinggi dalam hal rasa, emosional, agama/kepercayaan, tradisi, tempat tinggal, dan mata pencaharian (Devi, 2015). Hal ini salah satunya tercermin pada tradisi rewang yaitu kegiatan yang mengumpulkan orang-orang atau warga masyarakat dalam kegiatan pesta perkawinan. Tradisi ini menuntut partisipasi penuh masyarakat, karena tanpa partisipasi masyarakat, tradisi ini sama sekali tidak mungkin dilaksanakan. Setiap anggota masyarakat yang diundang, biasanya menunjukkan partisipasi aktif dengan menghadiri undangan tersebut. Apabila mereka tidak dapat menghadirinya, maka mereka tetap berpartisipasi dengan cara lain, misal memberikan sumbangan uang (Hasbullah, 2012). Hal menarik dalam tradisi ini adalah kemampuannya untuk melibatkan banyak orang, meskipun berasal dari kelompok ekonomi yang berbeda, tingkat pendidikan yang berbeda, juga diikuti oleh segenap lapisan, baik generasi tua maupun generasi muda (Hasbullah, 2012).

Berbeda dengan solidaritas yang ditunjukkan pada tradisi rewang, solidaritas di komunitas adat Cijere nampak dalam bentuk gotong-royong merawat rumah adat mereka. Banyak warga yang turut berpartisipasi hadir di rumah adat ketika ada suatu kegiatan tertentu. Seperasaan, sepenanggungan, dan saling membutuhkan sebagai unsur-unsur solidaritas masih melekat dalam kehidupan mereka.

"Begitu mendengar akan ada tamu
yang datang, maka tanpa disuruh, war-
ga otomatis kerja bakti membersihkan
rumah adat." (Wawancara dengan
Yayat, 19 September 2018)

Warga komunitas adat Cijere memiliki perasaan yang sama bahwa ada kewajiban moral untuk saling membantu, saling peduli, dan saling bekerja sama untuk melestarikan dan mempertahankan adat istiadat mereka. Sikap saling membutuhkan dan peduli di antara mereka juga sangat tinggi. Mereka per- 
caya semua dapat berjalan dengan baik apabila satu sama lain saling menjaga sikap dan tindakan mereka. Mereka memiliki kemauan kolektif, bersikap tanpa paksaan, dan bersifat spontan dalam merawat rumah adat sehingga walaupun tidak ada pembagian tugas merawat rumah adat, kondisi rumah adat pada saat itu terlihat bagus dan terawat.

Namun, saat ini situasi sudah berubah. Rumah adat dapat diibaratkan seperti dalam kondisi "hidup enggan, mati tidak mau". Rumah menjadi kotor, lapuk, reyot, kumuh, dapur dan toilet sudah rusak, sehingga kurang layak untuk digunakan. Jenis solidaritas yang berlaku pada komunitas adat Cijere pada hal-hal tertentu masih menunjukkan pada solidaritas yang bersifat tradisional, solidaritas yang lebih mengutamakan kepentingan kelompok, biasanya disebut dengan solidaritas mekanik.

Bentuk solidaritas mekanik, dijumpai pula pada kehidupan masyarakat nelayan di wilayah Samadikun Selatan. Masyarakatnya masih memegang tinggi nilai-nilai sosial yang terkandung dalam tradisi nadran, yaitu tradisi sedekah laut sebagai bentuk rasa syukur kepada Sang Khalik yang telah memberikan keunggulan di sektor perikanan dan kelautan. Hal ini terbukti dari adanya keyakinan dan kepercayaan terhadap nilai agama dan nilai moral yang terkandung di dalam tradisi $n a-$ dran, sehingga masyarakat bertindak dengan kesadaran diri sendiri. Selain itu, sistem pembagian kerja pada masyarakat nelayan terbilang rendah, karena masyarakat lebih sering melakukan tindakan secara kolektif. Oleh sebab itu, bentuk solidaritas masyarakat nelayan di wilayah Samadikun Selatan adalah bentuk solidaritas mekanik (Saeful, Achdiani, dan Abdullah, 2017).

Seiring dengan berjalannya waktu, solidaritas mekanik yang ada di komunitas adat Cijere semakin bergeser ke arah solidaritas yang lebih mementingkan individu, disebut solidaritas organik. Hal ini tercermin dari pudarnya gotong royong warga dalam merawat rumah adat. Sebenarnya, warga sudah membentuk kesepakatan umum terkait tanggung jawab dalam membersihkan rumah adat. Mereka bersepakat bahwa siapapun yang melewati rumah adat, apabila terlihat bala (kotor) dan loba runtah (banyak sampahnya), maka harus membersihkannya. Namun, kesepakatan tersebut nampaknya tidak berlaku lagi untuk masa sekarang.

Nilai-nilai tentang kebersamaan, tolong menolong, dan bergotong royong memang merupakan bagian yang tak terpisahkan dari kehidupan warga Cijere. Namun, di sisi lain, nilai-nilai individualis juga masih banyak ditemukan pada warga Cijere. Warga semakin sulit untuk diajak melakukan rembug desa, kerja bakti, atau kegiatan-kegiatan lain. Sebagian warga kini menganggap bahwa kegiatan-kegiatan itu menyita waktu, tidak menguntungkan secara materiel, dan mereka tidak memiliki waktu untuk berpartisipasi.

Salah satu bentuk solidaritas yang masih dapat ditemukan walaupun hanya sedikit di komunitas adat Cijere adalah kegiatan gotong royong dalam menyelenggarakan upacara adat, membangun rumah, memperbaiki jalan desa, dan membersihkan saluran air. Namun, masih saja ada beberapa warga yang sangat sulit untuk diajak terlibat dalam kegiatan tersebut. Begitu pula halnya dengan eksistensi rumah adat, hampir semua pihak saling melempar tanggung jawab. Kebersamaan dan kepercayaan yang selama ini terjalin dengan baik di antara sesama warga, sedikit demi sedikit sudah mulai terkikis.

Solidaritas mekanik adalah tipe solidaritas yang didasarkan atas persamaan, belum terdapat pembagian kerja yang berarti, dan biasanya hal yang dapat dilakukan oleh seseorang dapat dilakukan pula oleh orang lain (Durkheim dalam Sunarto, 2004). Tipe solidaritas yang didasarkan atas kepercayaan dan setia kawan ini diikat oleh apa yang disebut Durkheim dengan conscience collective (hati nurani kolektif). Gejala tersebut masih dijumpai pada komunitas adat Cijere. Hati nurani kolektif menggerakkan masyarakat untuk melakukan kerja bakti membersihkan rumah adat seperti menyapu, mengepel, mengecat, membersihkan rumah, dan merapikan rumah 
adat. Rumah adat adalah milik bersama; nilainilai tentang perlunya kepentingan bersama merupakan hal utama yang membuat mereka melakukannya.

Di sisi lain, lambat laun pembagian kerja dalam masyarakat mengalami proses diferensiasi, spesialisasi, dan semakin berkembang sehingga solidaritas mekanik berubah menjadi solidaritas organik. Berbeda dengan solidaritas mekanik yang didasarkan pada hati nurani kolektif, solidaritas organik didasarkan pada hukum dan akal. Pada komunitas adat Cijere, masyarakat tidak lagi dapat memenuhi semua kebutuhannya sendiri melainkan mereka mulai mengalami saling ketergantungan yang besar dengan orang atau kelompok lain.

Berdasarkan hasil observasi dan hasil wawancara langsung dengan informan, masyarakat komunitas adat Cijere masih memiliki kesadaran kolektif dan memiliki rasa kebersamaan, terutama pada hal-hal tertentu seperti dalam pemeliharaan rumah adat. Namun, dalam aspek lain seperti menanam padi, bentuk solidaritas tersebut sudah tidak ditemukan lagi.

Sebenarnya, nilai kebersamaan tentang kegotongroyongan juga masih melekat dalam kehidupan mereka. Namun, karena sebagian warga mengalami kekurangan ekonomi, maka sistem gotong royong yang diharapkan adalah warga masing-masing berperan sesuai keadaan ekonomi mereka. Warga yang berkecukupan secara ekonomi dapat bergotong royong dengan memberikan sumbangan materiel, sementara warga yang mengalami kekurangan ekonomi dapat menyumbang tenaga. Hal ini juga berlaku dalam kegiatan merenovasi rumah adat. Warga mau menyumbangkan tenaga mereka untuk melakukan kerja bakti, tetapi mereka tidak memiliki biaya untuk membeli bahan-bahan bangunan, sehingga kegiatan ini tidak terealisasi hingga sekarang. Pada awalnya, warga masih mempunyai uang kas untuk keperluan memelihara rumah adat, tetapi sekarang tidak ada lagi sisa hasil usaha dari kegiatan adat.

"Warga mau bergotong royong kalau ada materielnya, kalau ada uangnya, maksudnya uangnya itu akan dipakai untuk membeli bahan bangunannya, sedangkan pengerjaannya bisa dikerjakan bersama-sama secara gorong royong." (Wawancara dengan Yayat, Rabu, 19 September 2018)

Secara adat, mereka masih menjunjung prinsip nilai saling memaafkan dan tidak menyimpan dendam antar warga, dan tidak melakukan tindakan-tindakan yang melanggar hukum.

"Orang tidak akan takut keluar malam karena di sini tidak ada pencuri, kalaupun ada pencuri, pasti orang luar." (Wawancara dengan Yayat, 15 September 2018)

Rumah-rumah warga yang tanpa pagar dapat menunjukkan bahwa nilai saling percaya berkembang di antara mereka. Mereka mempunyai prinsip untuk tidak menghalalkan hal yang haram dan tidak pula mengharamkan yang halal.

\section{Faktor Penyebab Bergesernya Solidaritas Sosial}

Solidaritas sosial dalam suatu masyarakat cenderung berubah seiring dengan berjalannya waktu. Terkait dengan eksistensi rumah adat komunitas Cijere, pada awalnya warga menganggap rumah adat dengan segala sarana dan prasarananya adalah milik kolektif, sehingga tanggung jawab untuk merawat rumah adat tidak secara khusus dibebankan kepada orang tertentu, melainkan menjadi tanggung jawab bersama.

Solidaritas yang bernuansa alturisme masih ditemukan saat itu. Comte dalam Robet (2013) mendefinisikan altruisme sebagai "living for others". Altruisme adalah tanda positivitas manusia dan tanda positivitas dunia sosialnya. Melalui alturisme, sebuah masyarakat menemukan bahwa "bersama" itu mungkin dan bahwa perjumpaan dengan yang lain selalu membawa gairah. Oleh karenanya, altruisme juga penting untuk dijadikan sandaran bagi pembangunan hubungan kemasyarakatan. Momen 
individual bertransformasi menjadi momen kebersamaan ketika momen altruistik meningkat menjadi momen solidaritas (Robet, 2013).

Unsur-unsur sentimen komunitas yang memengaruhi solidaritas terdiri atas faktor seperasaan, sepenanggungan dan saling butuh sudah berkurang. Faktor seperasaan saat ini hanya dimiliki oleh golongan tua saja, seperti tokoh adat, tokoh masyarakat, dan tokoh desa. Di sisi lain, golongan muda kurang memiliki tanggung jawab moral maupun materiel terhadap kelompoknya. Mereka tidak lagi/kurang memiliki perasaan in-group di dalam kelompoknya.

Para pemuda komunitas adat Cijere kurang mau berpartisipasi dalam kegiatan-kegiatan yang berkaitan dengan upacara adat, termasuk kegiatan di rumah adat. Hal ini sejalan dengan pendapat Nuraiman (2019) yang menyatakan bahwa pada umumnya para generasi muda tidak mengindahkan lagi solidaritas dalam bentuk gotong royong, bahkan kesadaran kolektif juga melemah seiring berkembangnya zaman. Pemuda tidak lagi menunjukkan kebersamaan dan saling membantu dalam keadaan suka maupun duka karena mereka sibuk dengan pekerjaan mereka sendiri sehingga waktu untuk membantu sesama mulai berkurang.

Kebudayaan dapat punah apabila tidak dapat beradaptasi dengan lingkungannya. Kebudayaan dalam hal ini adalah upacara adat dan rumah adat yang mungkin sudah kurang diminati oleh golongan muda karena bahasa pengantar dalam upacara adat menggunakan bahasa Sunda yang tidak lagi dapat dimengerti dengan baik oleh mereka. Bahasa Sunda kuno dan halus bisa jadi sangat membosankan bagi para pemuda.

Selain unsur seperasaan, unsur sepenanggungan pun hanya dimiliki oleh golongan tua. Namun, karena faktor usia, fisik mereka tidak kuat lagi melakukan peranannya secara maksimal. Hal ini misalnya dialami oleh Aki Yayat, ketua adat yang lama yang sudah berusia 84 tahun. Begitu pula dengan golongan tua lainnya, rata-rata usia mereka berada di atas 60 tahun, yang sebenarnya perlu regenerasi un- tuk melaksanakan peranannya terkait dengan pelaksanaan atau pelestarian adat istiadat di komunitas adat Cijere.

Faktor seperasaan dan sepenanggungan yang semakin memudar tentu memengaruhi perasaan saling membutuhkan di antara masyarakat. Mereka tidak lagi merasakan dirinya tergantung pada komunitasnya, baik secara fisik maupun secara psikologis. Kesadaran untuk memberikan bantuan material maupun nonmaterial dalam mempertahankan rumah adat kurang tertanam dalam kehidupan sebagian besar warga komunitas adat Cijere. Warga sulit sekali diajak berpartisipasi dan bergotong royong untuk membersihkan apalagi merenovasi rumah adat. Hingga kini, rencana warga yang ingin merenovasi rumah adat sejak dua tahun yang lalu, belum juga terealisasi.

Menurut cerita mereka, uang kas untuk pemeliharaan rumah adat yang biasanya didapatkan dari hasil kegiatan setelah upacara adat dilaksanakan, sekarang tidak ada lagi karena ketua pelaksana kegiatan rumah adat tidak pernah aktif. Biasanya, setelah upacara hajat lembur dan bubur suro selesai, mereka memiliki sisa kelebihan beras, gula, atau kelapa, yang dapat dijual. Uang hasil penjualan tersebut disisihkan untuk membeli peralatan dapur atau digunakan untuk membeli cat, paku, dan kayu untuk merawat rumah adat.

Selama ini ketua pelaksana kegiatan rumah adat komunitas Cijere adalah Bapak Amar, yang juga bekerja sebagai pengurus desa. Warga berharap berharap terpilihnya seorang pengurus desa sebagai ketua pelaksana kegiatan rumah adat dapat memudahkan koordinasi dan kerja sama dengan pihak desa. Namun, kenyataannya ia lebih fokus menjalankan tugas-tugas sebagai aparat desa, sehingga melupakan tugasnya sebagai ketua pelaksana rumah adat. Secara tidak langsung, situasi ini menimbulkan anggapan yang negatif warga komunitas adat terhadap aparat desa.

"Dulu aparat desa tidak duduk di kantor saja, tapi $80 \%$ di lapangan dan $20 \%$ di kantor desa. Jadi sekarang pamong 
desa bukan lagi seorang pamong rakyat karena $80 \%$ di kantor desa dan $20 \%$ di lapangan." (Wawancara dengan Sanjaya, 22 September 2018)

Pandangan warga komunitas yang kurang baik terhadap aparat desa dikhawatirkan mengarah pada sikap antipati terhadap aparat desa. Ketidakpercayaan (distrust) telah terjadi di antara warga dengan tokoh adat, tokoh masyarakat, dan aparat desa. Para tokoh ini seharusnya menjadi panutan untuk masyarakatnya, akan tetapi ternyata kurang dapat memberikan teladan. Namun, tokoh adat/tokoh masyarakat tersebut semakin sulit ditemukan. Mereka justru sering mencari keuntungan untuk dirinya sendiri dan kurang dapat mengayomi warganya. Salah seorang warga menyatakan begitu kesal dengan seorang tokoh adat yang kurang dapat bertanggung jawab terhadap tugasnya sebagai ketua pelaksana rumah adat.

"Tuh ari bebersih mah ku saya, tapi duitna mah ku batur."

(tuh kalau bersih-bersih oleh saya, tapi uangnya untuk orang lain.) (Wawancara dengan Sanjaya, 22 September 2018)

Selain itu, peranan tokoh adat yang semakin menurun dapat juga disebabkan oleh kondisi fisik mereka yang semakin lemah. Usia rata-rata tokoh adat berkisar 60 - 80 tahun, tergolong dalam usia tua. Kepala adat yang selama ini sangat berperan dalam mempertahankan rumah adat, adalah Abah Anang yang berusia 80 tahun. Beliau sudah tidak kuat lagi untuk berjalan naik turun dari rumah tempat tinggalnya ke lokasi tempat rumah adat. Peranan tokoh adat yang semakin terbatas, baik secara jasmani maupun rohani, sangat menghambat tugas mereka.

Sebenarnya, sudah ada upaya regenerasi tokoh adat kepada golongan muda/pemuda yang ada di komunitas adat Cijere. Namun, hal tersebut kurang membuahkan hasil. Hal ini terbukti dengan banyaknya golongan muda yang sudah tidak peduli lagi dengan nilai-nilai adat/budaya yang selama ini dilestarikan oleh golongan tua dan tokoh-tokoh adat. Ketidakpedulian golongan muda, yang cenderung acuh tak acuh terhadap nilai adat dan budaya, terlihat dari kurangnya partsipasi anak-anak muda untuk ikut mempersiapkan dan hadir dalam setiap upacara-upacara adat yang dilakukan. Anak-anak muda beralasan upacara adat sangat mengganggu kesibukan dan urusan pekerjaannya. Ada juga anggapan orang-orang yang tradisional saja yang masih percaya dengan nilainilai adat/budaya, dan itu hanya cocok untuk golongan tua.

Hal ini sejalan dengan pendapat Nasution (2009) yang menyatakan bahwa berdasarkan dimensi kultural, pergeseran solidaritas dapat terjadi karena penolakan terhadap bentuk-bentuk baru, cara hidup lama, dan penggantian bentuk-bentuk lama dengan bentuk-bentuk baru. Nampak bahwa ada penolakan dari generasi muda terhadap cara hidup lama, yang ingin digantikan dengan cara hidup yang baru, yang dianggap lebih rasional, praktis, dan tidak menatap ke masa lalu.

Selanjutnya, Nasution (2009) menjelaskan perubahan solidaritas pada dimensi interaksional dapat mengacu pada perubahan hubungan/relasi sosial di dalam masyarakat, karena jarak sosial dan peran aturan/hukum yang berlaku kurang ketat. Jarak sosial antara golongan tua dengan golongan muda semakin lebar. Faktor seperasaan, sepenanggungan, dan saling membutuhkan kurang dimiliki oleh golongan muda, yang hidup di zaman sekarang ini. Begitu pula halnya dengan longgarnya aturan/ hukum yang berlaku dalam komunitas adat Cijere, khususnya yang terkait dengan pembagian kerja, dalam mempertahankan atau melestarikan rumah adat yang bahkan tidak ada pembagian tugas dan tanggung jawab di antara anggotanya. Mereka hanya menunjuk ketua adat sebagai penanggung jawab atau pelaksana tugas rumah adat; sementara tidak ada kesepakatan formal untuk penunjukan anggota dan aturan lainnya. Struktur organisasi lembaga adat yang bertanggung jawab dalam mempertahankan rumah adat pun tidak ada.

\section{Simpulan}


Eksistensi rumah adat di komunitas adat Cijere telah mengalami perubahan. Tidak semua kalangan menganggap rumah adat sangat penting bagi kehidupan mereka. Hal ini berkaitan dengan perbedaan pandangan golongan tua dan golongan muda tentang rumah adat, dan pergeseran solidaritas sosial dari solidaritas mekanik menjadi solidaritas organik di masyarakat Cijere. Pergeseran solidaritas mekanik ke solidaritas organik di masyarakat Cijere disebabkan oleh semakin terbatasnya peran tokoh adat, adanya penolakan dari generasi muda terhadap cara hidup lama yang kurang rasional, dan adanya ketidakpercayaan (distrust) terhadap aparat desa, tokoh adat, dan tokoh masyarakat. Selain itu, perubahan zaman, kepentingan ekonomi, dan individualisme yang berkembang di masyarakat juga menjadi faktor yang menyebabkan terjadinya pergeseran solidaritas ini.

\section{Daftar Pustaka}

Devi, A. (2015). Solidaritas Sosial dalam Peristiwa Kematian pada Masyarakat Dusun Ngulu Tengah, Desa Pracimantoro, Kecamatan Pracimantoro, Kabupaten Wonogiri. Jurnal Ilmiah Pendidikan Sosiologi-Antropologi, 5(2).

Funay, Y. E. N. (2020). Indonesia dalam Pusaran Masa Pandemi: Strategi Solidaritas Sosial Berbasis Nilai Tradisi Lokal. JSAI: Jurnal Sosiologi Agama Indonesia, 1(2), 107-120. https://doi.org/10.22373/jsai.v1i2.509

Haba, J. (2010). Realitas Masyarakat Adat di Indonesia: Sebuah Refleksi. Jurnal Masyarakat Dan Budaya, 12(2), 255-276. https://doi.org/10.14203/jmb.v12i2.112

Hasbullah. (2012). Rewang: Kearifan Lokal dalam Membangun Solidaritas dan Integrasi Sosial Masyarakat di Desa Bukit Batu Kabupaten Bengkalis. Sosial Budaya, 9(2), 231-243. http://dx.doi.org/10.24014/sb.v9i2.385

Johnson, D. P. (1986). Teori Sosiologi Klasik dan Modern. Jakarta: Kepustakaan Populer Gramedia.

Nasution, Z. (2009). Solidaritas Sosial dan Partisipasi Masyarakat Desa Transisi. Malang: UMM Press.

Nuraiman. (2019). Faktor-Faktor yang Memicu Perubahan Solidaritas dalam Masyarakat di Nagari Solok Ambah Kabupaten Sijunjung. JIPA: Jurnal Ilmu Pendidikan Ahlusunnah,
2(2), 6-12.

Robet, R. (2013). Altruisme, Solidaritas, dan Kebijakan Sosial. Jurnal Sosiologi Masyarakat, 18(1), 1-18.

Saeful, D., Achdiani, Y., dan Abdullah, M. N. A. (2017). Bentuk Solidaritas Masyarakat Nelayan di Kelurahan Kasenden. Sosietas: Jurnal Pendidikan Sosiologi, 7(2), 416-419. https://doi.org/10.17509/sosietas.v7i2.10359

Saidang, S., dan Suparman, S. (2019). Pola Pembentukan Solidaritas Sosial dalam Kelompok Sosial antara Pelajar. Edumaspul: Jurnal Pendidikan, 3(2), 122-125.

Saputra, M. S. A., dan Satwikasari, A. F. (2019). Kajian Arsitektur Tradisional Sunda pada Desain Resort. Jurnal Arsitektur Tradisional Sunda Pada Desain Resort, 3(4), 65-74.

Sembiring, K. B. (2014). Perubahan Sosial pada Masyarakat Karo yang Bermigrasi ke Kota dari Kecamatan Mandau Kabupaten Bengkalis Riau. Skripsi. Medan: Pendidikan Antropologi Universitas Negeri Medan. http:// digilib.unimed.ac.id/18244/

Soelaiman, M. M. (1998). Dinamika Masyarakat Transisi Mencari Alternatif, Teori Sosiologi dan Arah Perubahan. Yogyakarta: Pustaka Pelajar.

Sunarto, K. (2004). Pengantar Sosiologi: Edisi Revisi. Jakarta: FE-UI.

Wiganingrum, A. (2013). Nilai Kearifan Upacara Tradisional Susuk Wangan sebagai Bentuk Solidaritas Sosial dan Pelestarian Lingkungan di Desa Setren Kecamatan Slogohimo Kabupaten Wonogiri. Skripsi. Surakarta: Pendidikan Sejarah Universitas Sebelas Maret. 